\title{
Effects of somatic cell score on milk yield and mid-infrared predicted composition and technological traits of Brown Swiss, Holstein Friesian, and Simmental cattle breeds
}

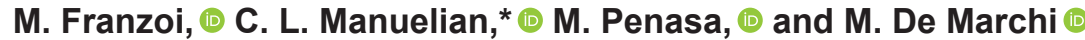 \\ Department of Agronomy, Food, Natural resources, Animals and Environment, University of Padova, 35020 Legnaro, Italy
}

\begin{abstract}
High milk somatic cell count (SCC) influences milk production and quality; however, very little is known about the effect of low SCC on milk quality, especially in terms of mineral content and coagulation properties. Thus, the present study aimed to investigate the effects of somatic cell score (SCS), calculated as $\log _{2}(\mathrm{SCC} / 100)$ +3 , on milk yield, composition (fat, crude protein, casein, lactose, milk urea nitrogen, protein fractions, and mineral contents), and coagulation properties of Brown Swiss, Holstein Friesian, and Simmental cows from multibreed herds. Milk composition and coagulation traits were predicted using mid-infrared spectroscopy. The data set comprised 95,591 observations of 6,940 cows in 313 multibreed herds, collected from January 2011 to December 2017. Observations were divided into 8 classes based on SCS. Statistical analysis was performed using a linear mixed model, which included breed, parity, stage of lactation, SCS class, and their interactions as fixed effects, and herd test day, cow, and residual as random effects. The probability that cows experienced SCS $>4.00$ at $30 \pm 5,60 \pm 5$, or $90 \pm 5 \mathrm{~d}$ after the observation test day was calculated for each SCS class, and odds ratios to the reference class $(-1.00$ $<\mathrm{SCS} \leq 0.00)$ were reported. Results showed that the relationship between SCS and milk traits followed a third-order polynomial regression. The average loss of milk, fat, and crude protein yields were $0.43,0.01$, and $0.01 \mathrm{~kg} / \mathrm{d}$, respectively, for each SCS unit higher than 1.00. Very low SCS $(<-1.00)$ had detrimental effects on milk yield and quality traits similar to or even stronger than high SCS (>4.00). Moreover, cows with SCS lower than -1.00 on a test day were about 7 times more likely to present high SCS within the following $90 \pm 5 \mathrm{~d}$ than cows with SCS between -1.00 and 0.00 .
\end{abstract}

Received May 6, 2019.

Accepted September 17, 2019.

*Corresponding author: carmenloreto.manuelianfuste@unipd.it
Breeds responded similarly to the increase of SCS, but the overall loss of fat and crude protein yields, and several minerals among Holstein Friesian were lower with increasing SCS. The best milk yield and quality were observed between SCS 0.00 and 1.00, but milk quality of Holstein Friesians started to decrease at lower SCS compared with milk quality of Brown Swiss and Simmental cows. Results suggest a breed-dependent optimum of SCS, and highlighted that very low SCS can be an indicator of udder health problems and, thus, may be used for early detection of mastitis.

Key words: mineral, phenotypic, coagulation property, somatic cell

\section{INTRODUCTION}

Milk and dairy consumption is steadily growing worldwide, and an important goal for researchers and farmers is to fulfill such increasing demand (IFCN Dairy Research Network, 2017). However, animal selection to increase milk yield has led to problems in terms of fertility, product quality, and technological properties (Berry et al., 2016). Moreover, high-yielding cows have increased risk of mastitis (Ingvartsen et al., 2003), and it has been demonstrated that a strong genetic correlation exists between milk yield and mastitis (Koivula et al., 2005). Milk SCC or SCS are the most frequently used indirect measures to detect mastitis, due to their moderate to strong associations $(\mathrm{r}=0.30$ to 0.80$)$ with mastitis (Koivula et al., 2005; Sharma et al., 2011; Arnould et al., 2013). For this reason, high SCC has been introduced as a basis for penalty in several milk payment systems worldwide (Halasa et al., 2007). Moreover, high SCC has been shown to impair milk yield (Seegers et al., 2003; Halasa et al., 2007) and quality traits such as fat, protein, and lactose contents (Seegers et al., 2003; Arnould et al., 2013; Visentin et al., 2018; Costa et al., 2019), technological properties (Ikonen et al., 2004; Visentin et al., 2018), and cheese yield and quality (Barbano et al., 1991; Klei et al., 1998). Consequently, high SCC has a negative economic effect for both farmers and cheese-producers. Nevertheless, 
the effect of SCS on milk protein fractions, mineral profiles, and milk coagulation properties (MCP) has been rarely investigated.

It has also been suggested that the relationships between SCS and mastitis, and between SCS and milk yield, are not linear. Indeed, several authors indicated that below some critical levels of SCC, the risk of mastitis increases (Suriyasathaporn et al., 2000; Peeler et al., 2003) and milk yield decreases (Tyler et al., 1989; Juozaitiene et al., 2006), just as for high SCS. However, information on the effect of low SCC on milk quality traits, including protein fractions, mineral contents, and MCP, is very scarce. Furthermore, little is known about the effect of somatic cells on these traits in different cattle breeds (Dürr et al., 2008).

The standard laboratory methods to determine milk protein fractions, mineral contents, and MCP are expensive and time consuming, and require trained personnel, hampering their application for population studies. The development of mid-infrared spectroscopy (MIRS) prediction models for milk protein fractions (McDermott et al., 2016; Niero et al., 2016), minerals (Franzoi et al., 2019a), and MCP (Visentin et al., 2015, 2016) has led to new opportunities to investigate the effect of somatic cells on these traits at population level; indeed, MIRS is a nondestructive and cost-effective method routinely used in laboratories to determine milk composition and record the spectral information of the sample (De Marchi et al., 2014). Therefore, this study aimed to investigate the effects of somatic cell levels on MIRS-predicted milk composition and MCP in multibreed herds of 2 specialized dairy cattle breeds (Holstein Friesian, HF, and Brown Swiss, BS) and 1 dual-purpose breed (Simmental, SI), the most widespread breeds in the study area. We hypothesized that different levels of somatic cells in milk have different effects in the studied breeds, and that very low SCC has detrimental effects on milk yield and quality.

\section{MATERIALS AND METHODS}

\section{Origin of the Data}

Milk composition data and spectral information of milk samples collected during routine monthly milk testing between January 2011 and December 2017 were retrieved from the South Tyrolean Dairy Association (Bolzano, Italy) and the Breeders Association of Bolzano Province (Bolzano, Italy). Milk samples (50 mL) were preserved with Bronysolv (200 $\mu \mathrm{L}$; ANA.LI.TIK Austria, Vienna, Austria) and analyzed in the laboratory of the South Tyrolean Dairy Association according to the guidelines of the International Committee for Animal Recording.
Fat, CP, CN, and lactose percentages, and MUN content of milk samples were determined using MilkoScan FT6000 until 2016 and using MilkoScan FT7 in 2017 (Foss Electric A/S, Hillerød, Denmark). To offset changes in instrumental response and ensure the comparability of spectra between MilkoScan FT6000 and MilkoScan FT7, the 2 instruments were routinely calibrated using a standard sample, according to the manufacturer's instructions (Feudalea and Woody, 2002; Juhl, 2017). Principal component analysis of spectra did not show significant differences between the 2 instruments. Casein number was defined as the ratio of $\mathrm{CN}$ to $\mathrm{CP}$. Somatic cell count (cells per microliter) was determined using Cell Fossomatic (Foss Electric) and transformed to SCS according to Wiggans and Shook (1987): SCS $=\log _{2}(\mathrm{SCC} / 100)+3$. The ECM was estimated according to Tyrrell and Reid (1965): $\mathrm{ECM}=12.82 \times$ fat $+7.13 \times \mathrm{CP}+0.323 \times$ milk yield, where fat, $\mathrm{CP}$, and milk yield were expressed in kilograms per day. Estimated milk value (EMV) per cow and test day was calculated using the most common penalties, rewards, and prices applied in Bolzano province, excluding the penalties and rewards associated with SCS and bacterial count. The base price that farmers received was $€ 0.30 / \mathrm{kg}$ of milk, $€ 0.035 / \mathrm{kg}$ of fat, and $€ 0.037 / \mathrm{kg}$ of CP. Farmers were penalized with $-€ 0.001 / \mathrm{kg}$ of milk for each millesimal point of the freezing point greater than $-0.515^{\circ} \mathrm{C}$, and from June to October farmers were rewarded with additional $€ 0.085 / \mathrm{kg}$ of milk.

\section{Prediction Models for Milk Composition and Coagulation Traits}

Spectral data from 5,000 to $900 \mathrm{~cm}^{-1}$ were stored to allow a posteriori application of the recently developed prediction models for milk protein fractions (Niero et al., 2016), MCP, and mineral composition (Visentin et al., 2016). Briefly, prediction models for absolute concentration (milligrams per milliliters) of $\alpha-\mathrm{CN}$ (as the sum of $\alpha_{\mathrm{S}^{-}}$and $\alpha_{\mathrm{S}^{2}} \mathrm{CN}$ ), $\beta-\mathrm{CN}, \kappa-\mathrm{CN}$, and $\alpha-\mathrm{LA}$ were developed using uninformative variable elimination procedure combined with partial least squares regression analysis and validated through leave-one-out cross-validation, matching the spectra with reference values of 114 individual cow milk samples analyzed through HPLC (Niero et al., 2016). Those samples were collected in 2015 in the same province as the present study and included HF $(\mathrm{n}=63)$, BS $(\mathrm{n}=26)$, and Jersey cows $(n=25)$. Coefficients of determination (root mean square error) in cross-validation were 0.88 $(1.05 \mathrm{mg} / \mathrm{mL}), 0.60(0.53 \mathrm{mg} / \mathrm{mL}), 0.74(0.88 \mathrm{mg} / \mathrm{mL})$, and $0.37(0.10 \mathrm{mg} / \mathrm{mL})$ for $\alpha-\mathrm{CN}, \beta-\mathrm{CN}, \kappa-\mathrm{CN}$, and $\alpha-L A$, respectively. Calibration for $\beta$-LG was developed from the same data set using backward interval PLS 
analysis (Franzoi et al., 2019b), and the coefficient of determination (root mean square error) in leave-oneout cross-validation was $0.66(0.79 \mathrm{mg} / \mathrm{mL})$. For the data analysis, predicted value for each protein fraction was then calculated as the ratio of fraction amount to CP.

Prediction models for MCP, namely rennet coagulation time (RCT, min), curd-firming time ( $\left.\mathbf{k}_{\mathbf{2 0}}, \mathrm{min}\right)$, and curd firmness 30 min after rennet addition to milk $\left(\mathbf{a}_{\mathbf{3 0}}, \mathrm{mm}\right)$, were also developed using uninformative variable elimination procedure combined with partial least squares regression analysis on 923 individual samples of HF $(\mathrm{n}=237)$, BS $(\mathrm{n}=223)$, Alpine Grey (n $=223)$, and SI cows $(\mathrm{n}=240)$ collected in 2014 in the same province as the present study. The reference analysis for MCP was lactodynamography, and prediction models were validated through external validation with $80 \%$ of the samples in the calibration set and $20 \%$ of the samples in the validation set (Visentin et al., 2016). Coefficients of determination (root mean square error) in external validation were $0.54(2.90 \mathrm{~min}), 0.56(1.22$ $\mathrm{min})$, and $0.52(9.00 \mathrm{~mm})$ for $\mathrm{RCT}, \mathrm{k}_{20}$, and $\mathrm{a}_{30}$, respectively. The index of milk aptitude to coagulate (IAC) was calculated as in Penasa et al. (2015): $\mathrm{IAC}=100$ $+\left(\mathrm{a}_{30}-\operatorname{mean}_{\mathrm{a} 30}\right) / \mathrm{SD}_{\mathrm{a} 30} \times 2.5-\left(\mathrm{RCT}-\operatorname{mean}_{\mathrm{RCT}}\right) /$ $\mathrm{SD}_{\mathrm{RCT}} \times 2.5$, where $\mathrm{SD}$ is the standard deviation. Prediction models for $\mathrm{Ca}, \mathrm{K}, \mathrm{Mg}, \mathrm{Na}$, and $\mathrm{P}$ contents $(\mathrm{mg} /$ $\mathrm{kg}$ ) in milk were also developed by Visentin et al. (2016) on a representative subset of 251 samples of $\mathrm{HF}$, BS, Alpine Grey, and SI cows analyzed through inductively coupled plasma optical emission spectrometry as reference method. Coefficients of determination (root mean square error) in external validation were 0.67 (122.00 $\mathrm{mg} / \mathrm{kg}), 0.69(120.00 \mathrm{mg} / \mathrm{kg}), 0.65(12.50 \mathrm{mg} / \mathrm{kg}), 0.40$ $(70.00 \mathrm{mg} / \mathrm{kg})$, and $0.68(88.12 \mathrm{mg} / \mathrm{kg})$ for $\mathrm{Ca}, \mathrm{K}, \mathrm{Mg}$, $\mathrm{Na}$, and $\mathrm{P}$, respectively.

\section{Data Editing}

The original data set contained 2,119,143 test days. Only records from multibreed herds with combinations of HF, BS, and SI cows from parity 1 to 15 and between 6 and 305 DIM were retained. Herds with less than $10 \%$ of individuals from a breed and cows with less than 3 test days per lactation were removed from the data set. Within breed, animals with age at calving that deviated more than $3 \mathrm{SD}$ from the respective breed parity mean were discarded. Contemporary groups were defined as cows tested in the same herd and date (herd test day, HTD) and HTD with less than 3 animals were deleted. Inconsistent values for the investigated traits - that is, those outside \pm 3 SD from the respective breed mean - were treated as missing. The final data set consisted of 95,591 records of 6,940 cows in 313 multibreed herds. Parity, DIM, and herd size averaged $2.65 \pm 1.63,152.32 \pm 82.87 \mathrm{~d}$, and $22.15 \pm 12.67$ cows, respectively. Herd size ranged from 6 to 113 cows. The frequency for each breed was as follows: HF, 2,352 cows and 31,902 records; BS, 2,799 cows and 38,795 records; and SI, 1,789 cows and 24,894 records. Herd combinations were: BS + HF (132 herds), BS + SI (63 herds), $\mathrm{HF}+\mathrm{SI}(81$ herds), and BS + HF + SI (37 herds).

\section{Statistical Analysis}

Sources of variation of milk yield, ECM, EMV, composition (fat, $\mathrm{CP}, \mathrm{CN}$, lactose, MUN, protein fractions, and mineral contents), SCS, and MCP were investigated using the HPMIXED procedure of SAS version 9.4 (SAS Institute Inc., Cary, NC) according to the following linear mixed model:

$$
\begin{aligned}
\mathrm{y}_{i j k l m n}=\mu+ & \mathrm{B}_{i}+\mathrm{S}_{j}+\mathrm{P}_{k}+\mathrm{C}_{l}+(\mathrm{B} \times \mathrm{C})_{i l} \\
+(\mathrm{S} \times \mathrm{P})_{j k}+ & (\mathrm{S} \times \mathrm{C})_{j l}+(\mathrm{P} \times \mathrm{C})_{k l}+\mathrm{HTD}_{m} \\
& +\mathrm{Cow}_{n}+\mathrm{e}_{i j k l m n},
\end{aligned}
$$

where $\mathrm{y}_{i j k l m n}$ is the analyzed trait; $\mu$ is the overall intercept of the model; $\mathrm{B}_{i}$ is the fixed effect of the $i$ th breed $(i=\mathrm{HF}, \mathrm{BS}$, or $\mathrm{SI}) ; \mathrm{S}_{j}$ is the fixed effect of the $j$ th DIM class ( $j=1$ to $30 ; 10$-d classes); $\mathrm{P}_{k}$ is the fixed effect of the $k$ th parity class $(k=1$ to 5 , with class 5 including parities $\geq 5) ; \mathrm{C}_{l}$ is the fixed effect of the $l$ th SCS class $(l$ $=-2$ to 5 ; class -2 , SCS $\leq-1.00$; class $-1,-1.00<$ $\mathrm{SCS} \leq 0.00 ;$ class $0,0.00<\mathrm{SCS} \leq 1.00 ;$ class $1,1.00<$ SCS $\leq 2.00 ;$ class $2,2.00<\mathrm{SCS} \leq 3.00 ;$ class $3,3.00<$ $\mathrm{SCS} \leq 4.00 ;$ class $4,4.00<\mathrm{SCS} \leq 5.00 ;$ class 5 , SCS $>$ $5.00) ;(\mathrm{B} \times \mathrm{C})_{i l}$ is the fixed interaction effect between breed and SCS class; $(\mathrm{S} \times \mathrm{P})_{j k}$ is the fixed interaction effect between DIM class and parity class; $(\mathrm{S} \times \mathrm{C})_{j l}$ is the fixed interaction effect between DIM class and SCS class; $(\mathrm{P} \times \mathrm{C})_{k l}$ is the fixed interaction effect between parity class and SCS class; $\mathrm{HTD}_{m}$ is the random effect of the $m$ th herd test day $(m=1$ to 8,572$) \sim N\left(0, \sigma_{H T D}^{2}\right)$, where $\sigma_{H T D}^{2}$ is the HTD variance; $\mathrm{Cow}_{n}$ is the random effect of the $n$th cow $(n=1$ to 6,940$) \sim N\left(0, \sigma_{C}^{2}\right)$, where $\sigma_{C}^{2}$ is the cow variance; and $\mathrm{e}_{i j k l m n}$ is the random residual $\sim N\left(0, \sigma_{e}^{2}\right)$, where $\sigma_{e}^{2}$ is the residual variance. The main effect of SCS class and the interactions that involved this factor were not included in the analysis of SCS. Multiple comparisons of LSM were performed for the main effect of breed, stage of lactation, parity, and SCS classes using Bonferroni adjustment. Frequency of observations for the interaction effects are reported in 
Supplemental Tables S1 to S4 (https://doi.org/10 .3168/jds.2019-16916). The best polynomial regression between the SCS classes and the analyzed traits was selected through polynomial contrasts up to a fifth-order polynomial. Significance was set at $P<0.05$, unless otherwise stated.

The odds ratio (OR) for each SCS class relative to the reference class (SCS class $-1,-1.00<\mathrm{SCS} \leq 0.00$ ) was calculated to estimate the likelihood that in at least one test day at $30 \pm 5,60 \pm 5$, or $90 \pm 5 \mathrm{~d}$ from the observation test day the cow would present SCS > 4.00 , which is the most common cutoff in Italy to consider a cow as mastitic (Piccinini et al., 2005). When at least 1 of the following test days was not available, the observation was deleted. This led to a reduction of the number of cows from 6,940 to 6,344. The OR were calculated using the GLIMMIX procedure of SAS version 9.4 (SAS Institute Inc.) according to the following linear mixed model:

$$
\begin{aligned}
\mathrm{y}_{i j k l m n o}= & \mu+\mathrm{B}_{i}+\mathrm{P}_{j}+\mathrm{C}_{k}+\mathrm{M}_{l}+\mathrm{Y}_{m} \\
& +\mathrm{Cow}_{n}+\mathrm{H}_{o}+\mathrm{e}_{i j k l m n o},
\end{aligned}
$$

where $\mathrm{y}_{i j k l m n o}$ is a binary variable, being 1 if at least 1 test day at $30 \pm 5,60 \pm 5$, or $90 \pm 5 \mathrm{~d}$ from the observation test day had SCS $>4.00$, and 0 if all those test days had $\mathrm{SCS} \leq 4.00 ; \mathrm{B}_{i}$ is the fixed effect of the $i$ th breed $(i=\mathrm{HF}, \mathrm{BS}$, or $\mathrm{SI}) ; \mathrm{P}_{j}$ is the fixed effect of the $j$ th parity class $(j=1$ to 5 , with class 5 including parities $\geq 5) ; \mathrm{C}_{k}$ is the fixed effect of the $k$ th SCS class $(k=$ -2 to 5 ; class -2 , SCS $\leq-1.00$; class $-1,-1.00<$ SCS $\leq 0.00 ;$ class $0,0.00<\mathrm{SCS} \leq 1.00 ;$ class $1,1.00<\mathrm{SCS}$ $\leq 2.00 ;$ class $2,2.00<\mathrm{SCS} \leq 3.00 ;$ class $3,3.00<\mathrm{SCS}$ $\leq 4.00$; class $4,4.00<\mathrm{SCS} \leq 5.00$; class 5 , $\mathrm{SCS}>5.00$ ); $\mathrm{M}_{l}$ is the fixed effect of the $l$ th month of sampling $(l=$ 1 to 12); $\mathrm{Y}_{m}$ is the fixed effect of the $m$ th year of sampling ( $m=2011$ to 2017); $\mathrm{Cow}_{n}$ is the random effect of the $n$th cow $(n=1$ to 6,344$) \sim N\left(0, \sigma_{C}^{2}\right) ; \mathrm{H}_{o}$ is the random effect of the oth herd $(o=1$ to 312$) \sim N\left(0, \sigma_{\mathrm{H}}^{2}\right)$, where $\sigma_{\mathrm{H}}^{2}$ is the herd variance; and $\mathrm{e}_{i j k l m n o}$ is the random residual $\sim N\left(0, \sigma_{e}^{2}\right)$. An additional analysis was performed using the same model as above but defining 3 levels for the fixed effect of SCS [low (SCS $\leq-1.00$ ), average $(-1.00<\mathrm{SCS} \leq 4.00)$, and high $(\mathrm{SCS}>4.00)$ ]. The reference SCS class for this model was the average one. Odds ratios were reported with the $95 \%$ Wald confidence interval (CI95\%); if the CI95\% overlapped 1 , which is the null hypothesis $(\mathrm{OR}=1)$, it indicated no significant association between the exposure variable and the outcome (Szumilas, 2010).

\section{RESULTS}

\section{Analysis of Variance}

The fixed effects of breed, parity, stage of lactation, and SCS significantly explained the variation of the studied traits, with the exception of parity for $\beta-\mathrm{CN}$, and SCS class for $\beta-\mathrm{LG}$ (Table 1). The interaction between stage of lactation and parity was significant for all the traits. The interaction between SCS class and breed was significant for all the traits, except for fat percentage; SCS class by stage of lactation interaction was significant for all the traits, except for milk K content; and SCS class by parity interaction was significant for most traits, with the exception of MUN, fat percentage, several protein fractions $(\alpha-\mathrm{CN}, \beta-\mathrm{CN}$, $\beta-\mathrm{LG}$, and $\alpha-\mathrm{LA}$ ), and $\mathrm{Ca}, \mathrm{K}$, and $\mathrm{P}$ content.

The variance explained by cow effect was greater than the variance explained by HTD effect for milk yield, ECM, and SCS; fat, CP, CN, and lactose yields and percentages; and $\mathrm{P}$ and $\mathrm{Na}$ content. For those traits, the cow effect explained about $50 \%$ of the variance, except for SCS, fat yield, fat percentage, $\mathrm{P}$ content, and $\mathrm{Na}$ content, for which the cow effect explained between 26 and $45 \%$ of the variance. The variance explained by HTD effect was greater than that explained by cow effect for EMV, MUN, CN number, all protein fractions, $\mathrm{Ca}, \mathrm{K}$, and $\mathrm{Mg}$ content, and $\mathrm{MCP}$, with values comprising between 38 and $87 \%$ (Table 1).

\section{Breed Effect}

Holstein Friesian cows produced about $4.20 \mathrm{~kg} / \mathrm{d}$ more milk than did BS and SI cows $(P<0.05)$, with lower fat, $\mathrm{CP}$, and $\mathrm{CN}$ percentages, and MUN content, and greater SCS (Table 2). However, fat, CP, CN, and lactose yields were greater for HF than for BS or SI ( $P$ $<0.05)$. Considering the prices in Bolzano province, the EVM was $€ 1.47 / \mathrm{d}$ and $€ 1.37 / \mathrm{d}$ higher for HF than BS and SI, respectively (Table 2). Milk composition (percentage and yield), CN number, and MUN were greater in BS than in SI $(P<0.05)$, except for lactose yield (Table 2). Milk CP was mainly composed of $\alpha-\mathrm{CN}$ (between 42.53 and $43.19 \%$ ) and $\beta$-CN (between 28.10 and $30.20 \%$ ), with slight differences among breeds $(P$ $<0.05$; Table 2). Milk of BS had greater proportion of $\beta-\mathrm{CN}$ and $\kappa-\mathrm{CN}$, and lower proportion of $\beta-\mathrm{LG}$ and $\alpha$-LA than the other breeds. Milk of SI was richer in $\alpha-\mathrm{CN}$ and $\beta-\mathrm{LG}$, and poorer in $\beta-\mathrm{CN}$ than the other breeds. Regardless of the breed, the most abundant minerals were Ca (between 1,314 and 1,404 mg/kg), K (between 1,485 and 1,508 mg/kg), and P (between 979 
Franzoi et al.: EFFECTS OF SCS ON MILK QUALITY TRAITS

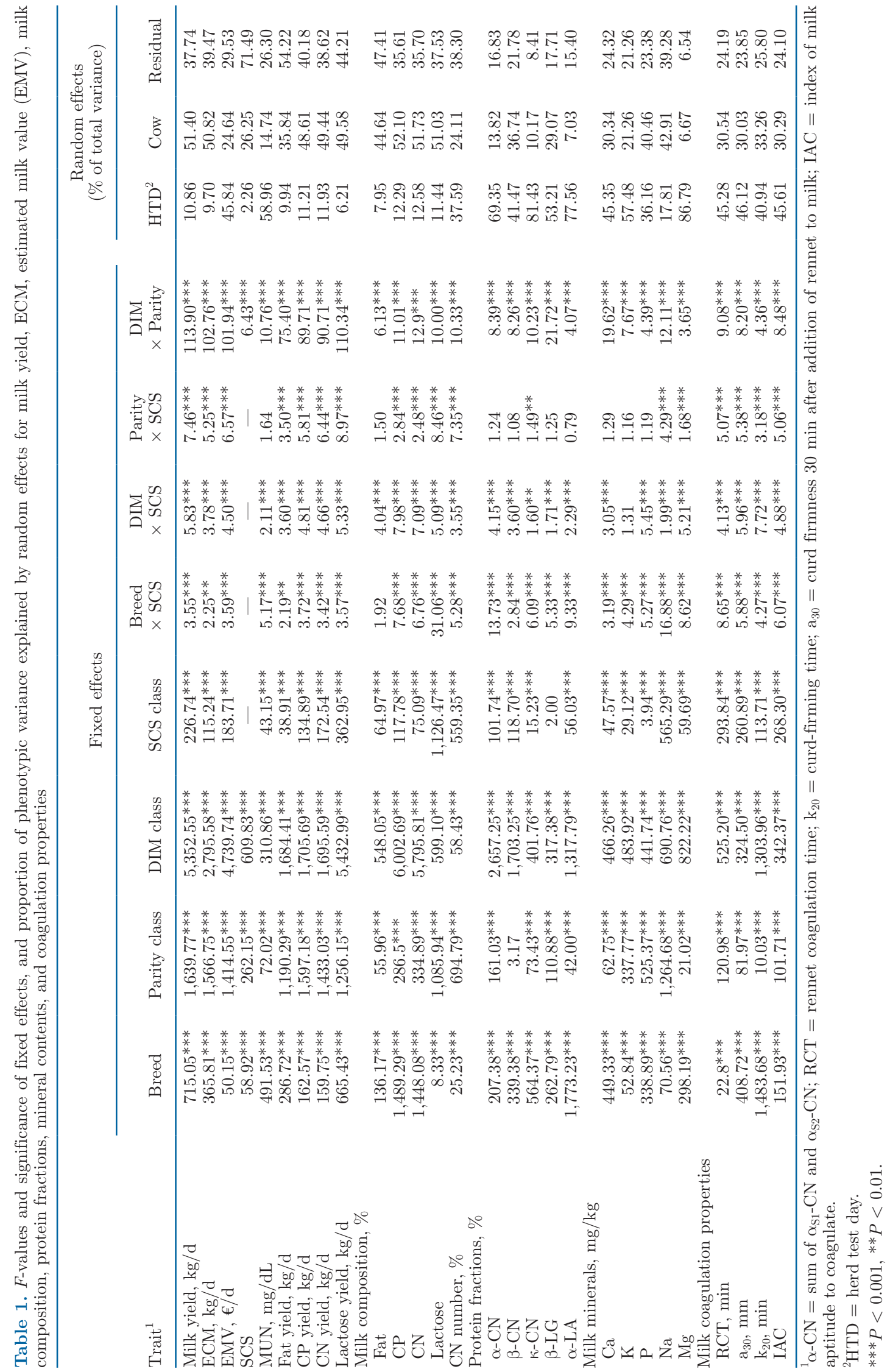


and $1,034 \mathrm{mg} / \mathrm{kg}$; Table 2). The $\mathrm{Ca}$ and $\mathrm{Mg}$ contents differed among breeds, with the highest content for SI and the lowest for HF. Moreover, milk of BS had the lowest content of $\mathrm{K}$, and milk of HF had the highest content of $\mathrm{Na}$ and the lowest of $\mathrm{P}$ (Table 2). Milk of HF coagulated later, required longer time to reach the 20 $\mathrm{mm}$ of coagulum, and had weaker curd firmness than milk of the other breeds, resulting in the lowest IAC $(P$ $<0.05$; Table 2).

\section{Effects of SCS on Production Traits}

Similar trends for milk yield, ECM, EMV, and milk component yields (Figure 1) were obtained for BS, HF, and SI across SCS classes. The greatest values for all traits were observed in SCS class -1 for BS and HF, and in class 0 for SI, with decreasing values thereafter. When milk composition was expressed as percentage, a similar pattern was observed for lactose, whereas fat, $\mathrm{CP}$, and $\mathrm{CN}$ percentages had an opposite trend, with
SCS class 0 having the lowest contents (Supplemental Figure S1; https://doi.org/10.3168/jds.2019-16916).

Overall, milk yield decreased by $7.53,8.60$, and $8.62 \%$ moving from SCS class -1 (class 0 for SI) to SCS class 5 for BS, HF, and SI, respectively, with an average loss of $0.43 \mathrm{~kg} / \mathrm{d}$ for each SCS unit higher than 1.00. The decrease was less marked for ECM $(5.77 \%$ for BS, $5.22 \%$ for HF, and $6.87 \%$ for SI). Regarding EMV, daily income from milk in SCS class 5 was €0.65, €0.84, and $€ 0.76$ lower than daily income from milk in SCS class -1 (class 0 for SI) for BS, HF, and SI, respectively (Figure 1). The effect of SCS class on fat yield was less pronounced for HF than BS and SI; indeed, HF lost $2.68 \%$ fat yield in SCS class 5 compared with the SCS class with the greatest fat yield, and BS and SI lost 4.00 and $5.31 \%$, respectively. The average fat yield reduction was $0.010 \mathrm{~kg} / \mathrm{d}$ for each SCS unit higher than 1.00. Protein yield decreased by $5.76,4.40$, and $7.02 \%$, and $\mathrm{CN}$ yield by $6.50,5.15$, and $7.77 \%$ for $\mathrm{BS}, \mathrm{HF}$, and SI, respectively. The average loss of $\mathrm{CP}$ yield was

Table 2. Least squares means ( \pm SE) of milk yield, ECM, estimated milk value (EMV), milk composition, protein fractions, mineral contents, and coagulation properties of cows of different breeds

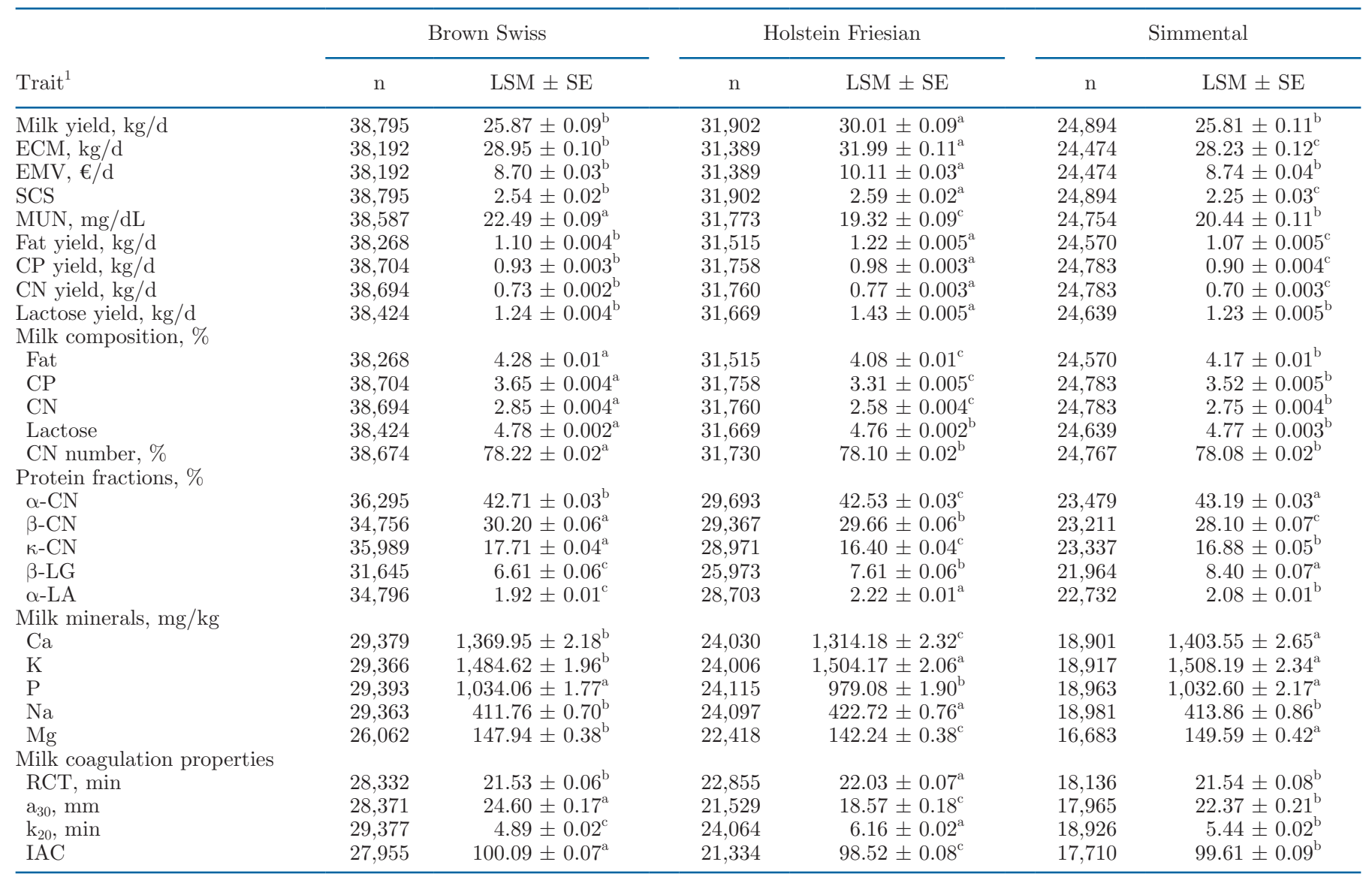

\footnotetext{
${ }^{\mathrm{a}-\mathrm{c}}$ Least squares means with different superscript letters within a row are significantly different $(P<0.05)$.

${ }^{1} \alpha-\mathrm{CN}=$ sum of $\alpha_{\mathrm{S}^{-}} \mathrm{CN}$ and $\alpha_{\mathrm{S} 2}-\mathrm{CN} ; \mathrm{RCT}=$ rennet coagulation time; $\mathrm{k}_{20}=$ curd-firming time; $\mathrm{a}_{30}=$ curd firmness 30 min after addition of rennet to milk; IAC $=$ index of milk aptitude to coagulate.
} 
a
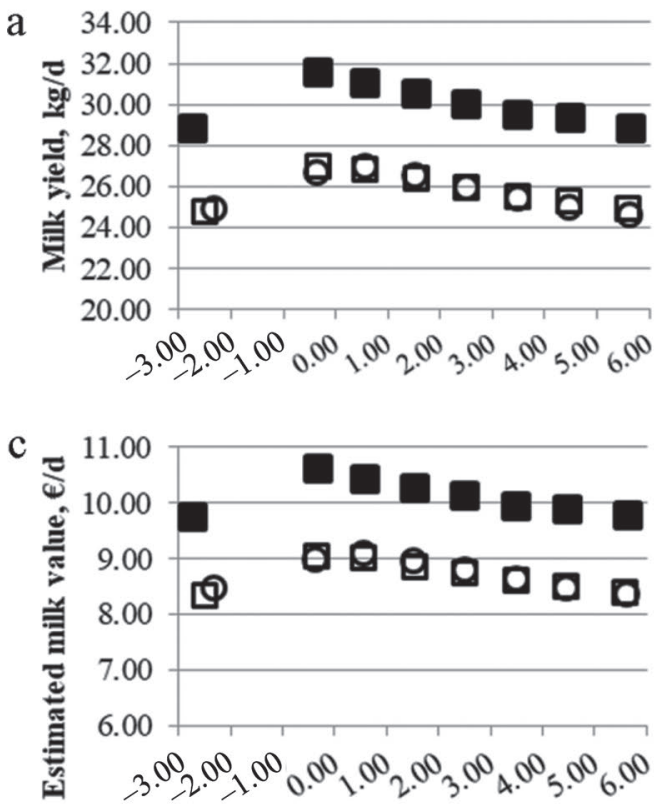

$\mathrm{e}$
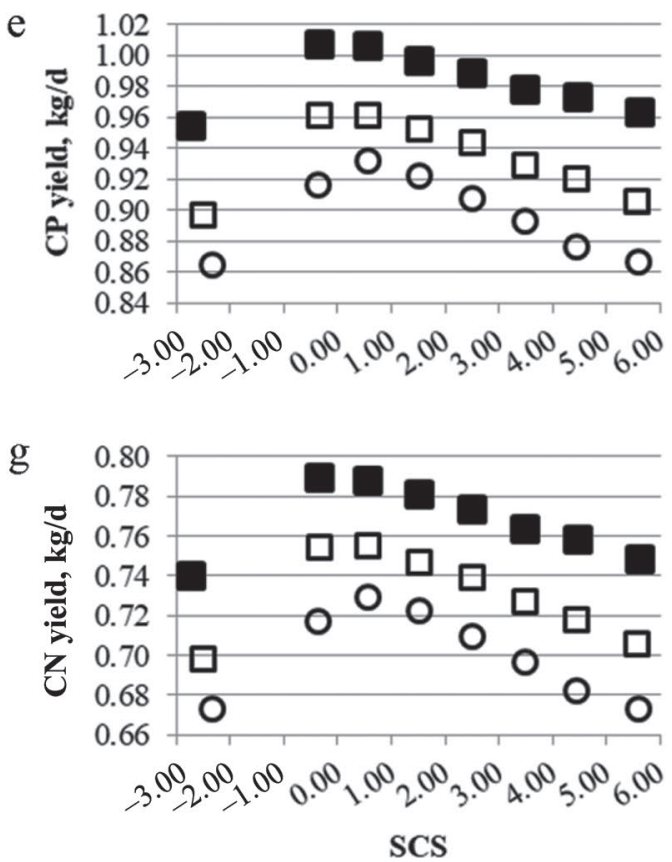
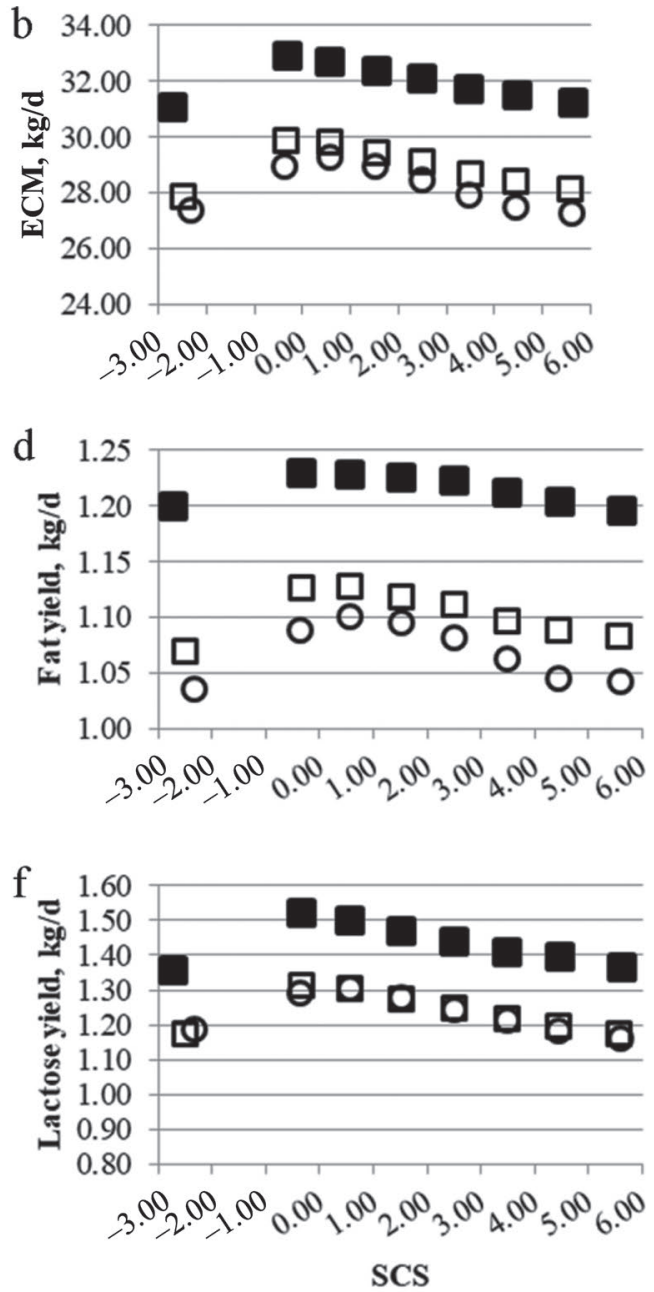

ses

Figure 1. Least squares means of (a) milk yield, (b) ECM, (c) estimated milk value, (d) fat yield, (e) CP yield, (f) lactose yield, and (g) CN yield across SCS for Brown Swiss $(\square)$, Holstein Friesian $(\mathbf{\square})$, and Simmental $(\bigcirc)$ cows in multibreed herds. For each breed, represented data points are means of each variable for each SCS class.

$0.011 \mathrm{~kg} / \mathrm{d}$ for each SCS unit higher than 1.00. The increase of SCS affected the lactose yield more than it did the other milk components, being in all breeds about $10.50 \%$ lower in SCS class 5 compared with the SCS class with the greatest lactose yield. Casein numbers differed less than $1 \%$ between the highest and lowest values. The MUN tended to decrease at higher SCS, but differences among classes, even if statistically significant, were negligible.

The lowest SCS class in this study (SCS class -2), which corresponded to $\mathrm{SCC} \leq 6,250$ cells $/ \mathrm{mL}$, had milk yield, ECM, EMV, and milk composition yields that 
were similar to or worse than those observed in SCS classes 4 and 5 (SCS > 4.00). Thus, the impairment of milk production and milk quality traits for SCS class -2 was of similar magnitude to the overall loss reported above.

\section{Effects of SCS on Milk Protein Fractions, Mineral Contents, and MCP}

Similar trends for milk protein fractions (Figure 2), mineral contents (Figure 3), and MCP (Figure 4) were observed for the 3 breeds across SCS classes. Regarding protein fractions, $\alpha-\mathrm{CN}$ and $\beta-\mathrm{CN}$ showed opposite patterns; whereas $\alpha-\mathrm{CN}$ increased from SCS class -1 to $5, \beta-\mathrm{CN}$ decreased. As reported above, values of $\alpha-\mathrm{CN}$ and $\beta-\mathrm{CN}$ in SCS class -2 were similar to those ob- served in SCS class 5 . The other milk protein fractions were almost stable across SCS classes (Figure 2).

Calcium, K, Na, and Mg increased from SCS class -1 or 0 , depending on the breed, to SCS class 5 (Figure 3 ). The greatest increase was observed for $\mathrm{Na}$ content (between 6.51 and $8.87 \%$ ), followed by $\mathrm{Mg}$ (1.40 to $3.02 \%$ ), $\mathrm{Ca}$ (1.51 to $2.07 \%)$, and $\mathrm{K}$ (0.74 to $1.60 \%)$, with the lowest variation for $\mathrm{HF}$ and the greatest for BS breed. On the other hand, $\mathrm{P}$ content remained almost stable across SCS classes for all the breeds (data not shown). The mineral contents of SCS class -2 were also similar to those of SCS class 5 .

Rennet coagulation time increased between 1.60 and 1.91 min from SCS class -1 or 0 (depending on the breed) to SCS class 5 , whereas $\mathrm{a}_{30}$ and IAC decreased between 3.66 and $4.60 \mathrm{~mm}$, and between 1.70 and a

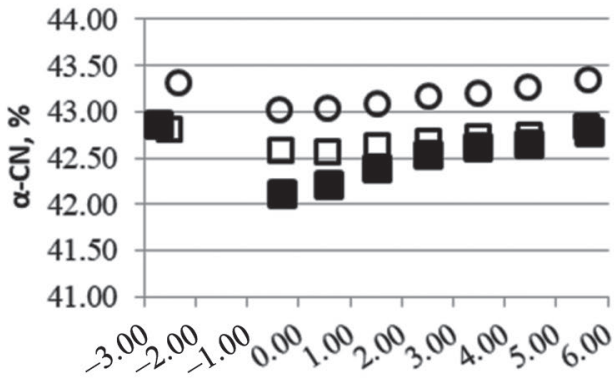

c

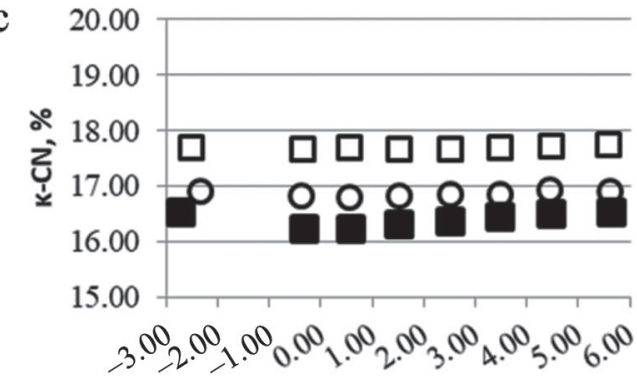

e

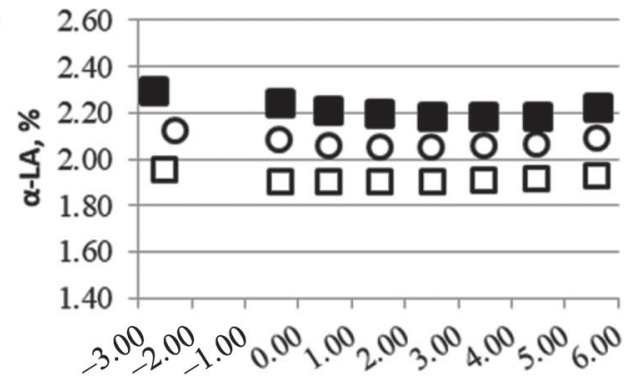

b

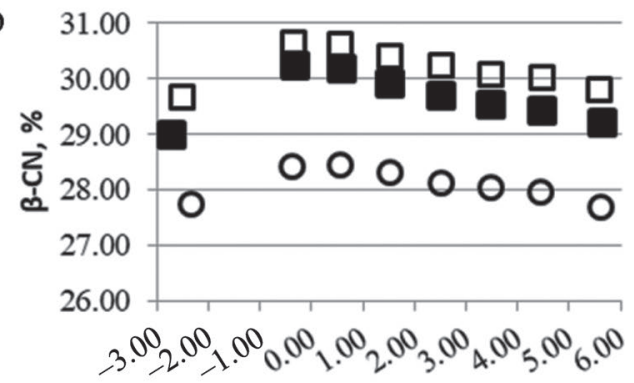

d

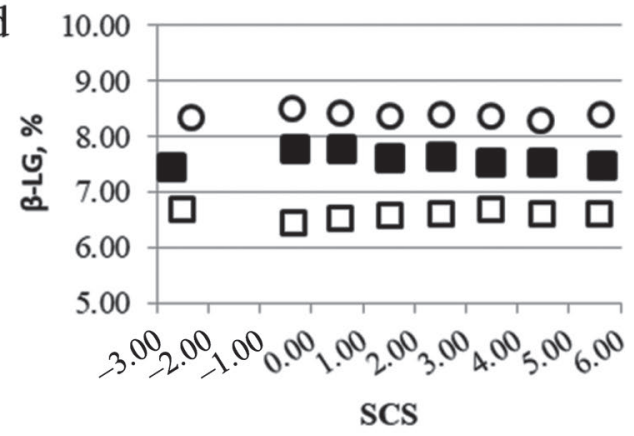

Figure 2. Least squares means of (a) $\alpha-\mathrm{CN}$, (b) $\beta-\mathrm{CN}$, (c) $\kappa-\mathrm{CN}$, (d) $\beta-\mathrm{LG}$, and (e) $\alpha$-LA across SCS for Brown Swiss ( $\square$ ), Holstein Friesian $(\square)$, and Simmental $(\bigcirc)$ cows in multibreed herds. For each breed, represented data points are means of each variable for each SCS class. 
a
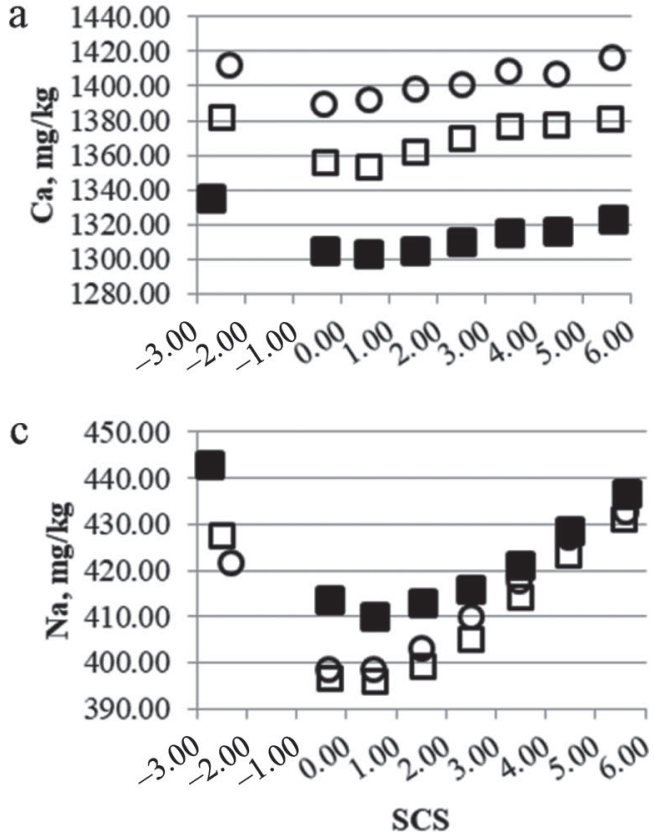

b

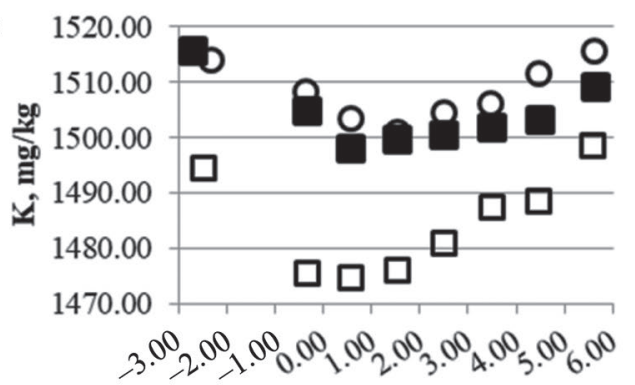

d

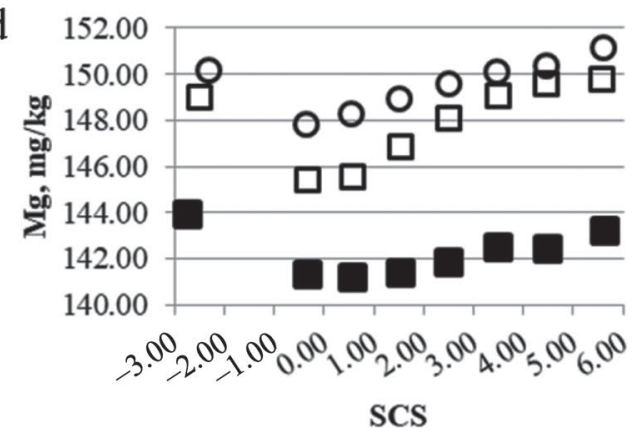

Figure 3. Least squares means of (a) Ca, (b) K, (c) Na, and (d) Mg content across SCS for Brown Swiss ( $\square$ ), Holstein Friesian (ם), and Simmental $(\bigcirc)$ cows in multibreed herds. For each breed, represented data points are means of each variable for each SCS class.

2.05, respectively (Figure 4). On the other hand, $\mathrm{k}_{20}$ was quite stable across SCS classes. Milk coagulation properties of HF cows in SCS class -2 were worse than those in SCS class 5 (longer RCT and $\mathrm{k}_{20}$, weaker $\mathrm{a}_{30}$, and lower IAC).

\section{Polynomial Regressions for Milk Yields, $E M V$, and MCP}

Least squares means of milk yield traits, EMV, and MCP were interpolated for each breed with a thirdorder polynomial, which resulted in $\mathrm{R}^{2} \geq 0.96(P<$ 0.001; Table 3) for all traits. The best SCS, resulting in the highest milk yield, ECM, EMV, and milk component yields, was lower for HF compared with BS and SI, except for fat yield and CN number, which were greater for $\mathrm{HF}$ than for BS. An opposite pattern was observed for MCP, where the best SCS, resulting in the most desirable MCP, were greater in $\mathrm{HF}$ than in $\mathrm{BS}$ or SI. Most of the desirable estimated SCS values were in SCS class 0, with very few exceptions.

\section{Evolution of SCS on Consecutive Test Days}

On average, 34.04, 33.15, and $33.87 \%$ of the cows that presented low SCS (SCS $\leq-1.00)$ in a test day moved to a high SCS (SCS > 4.00) in the following 3 test days at $30 \pm 5,60 \pm 5$, or $90 \pm 5 \mathrm{~d}$, respectively. Also, $53.06 \%$ of cows with low SCS had high SCS in at least 1 test day within the next $90 \pm 5 \mathrm{~d}$. On the other hand, only $24.60 \%$ of cows with SCS between -1.00 and 4.00 on a test day moved to a high SCS in at least 1 test day within the next $90 \pm 5 \mathrm{~d}$.

The OR obtained when evaluating the probability of a cow to move to a high SCS in the subsequent test days for each class of SCS, considering SCS class -1 $(-1.00<\mathrm{SCS}<0.00)$ as the reference, are presented in Figure 5. The OR indicated an increased risk of SCS $>4.00$ within $90 \pm 5 \mathrm{~d}$ from the test day, for SCS other than -1 and 0 . Cows that were in SCS class above 0 exhibited a greater probability to reach a high SCS in the subsequent test days, and the probability increased with SCS classes. Cows that had SCS lower than -1.00 presented a greater probability to reach high SCS during the following test days, compared with the reference class. Cows in SCS class -2 presented a similar OR to cows in SCS class 3 (OR 6.77 and 8.05, respectively). Moreover, OR for SCS class -2 was greater than for SCS class 2. Cows in SCS classes 4 and 5 were 14 and 20 times, respectively, more likely to present SCS > 4.00 within the following $90 \pm 5 \mathrm{~d}$, compared with cows in SCS class 0.

Results from the model, which considered only 3 levels of SCS (low, average, or high), indicated that observations from SCS class low (SCS $\leq-1.00)$ were $2.86(\mathrm{CI} 95 \%=2.40$ to 3.41$)$ times more likely to present high SCS in subsequent test days than were observations from SCS class average. The observations 
Table 3. Estimated optimal SCS $\left(\mathrm{R}^{2}\right)$ for milk yield, ECM, estimated milk value (EMV), milk component yields, and milk coagulation properties, based on a third-order polynomial regression; all regressions were significant $(P<0.001)$

\begin{tabular}{|c|c|c|c|}
\hline Trait $^{1}$ & Brown Swiss & Holstein Friesian & Simmental \\
\hline Milk yield, $\mathrm{kg} / \mathrm{d}$ & $0.14(0.97)$ & $-0.07(0.96)$ & $0.26(0.99)$ \\
\hline $\mathrm{ECM}, \mathrm{kg} / \mathrm{d}$ & $0.23(0.99)$ & $0.10(0.98)$ & $0.34(0.99)$ \\
\hline $\mathrm{EMV}, € / \mathrm{d}$ & $0.17(0.97)$ & $-0.11(0.96)$ & $0.26(0.99)$ \\
\hline Fat yield, $\mathrm{kg} / \mathrm{d}$ & $0.34(0.99)$ & $0.38(0.99)$ & $0.50(0.99)$ \\
\hline $\mathrm{CP}$ yield, $\mathrm{kg} / \mathrm{d}$ & $0.44(0.99)$ & $0.20(0.98)$ & $0.49(0.99)$ \\
\hline $\mathrm{CN}$ yield, $\mathrm{kg} / \mathrm{d}$ & $0.46(0.99)$ & $0.29(0.98)$ & $0.51(0.99)$ \\
\hline Lactose yield, $\mathrm{kg} / \mathrm{d}$ & $0.13(0.98)$ & $0.03(0.97)$ & $0.21(0.99)$ \\
\hline $\mathrm{CN}$ number, $\%$ & $0.62(0.99)$ & $0.72(0.99)$ & $0.81(0.99)$ \\
\hline \multicolumn{4}{|c|}{ Milk coagulation properties } \\
\hline $\mathrm{RCT}$, min & $0.31(0.99)$ & $0.73(0.99)$ & $0.17(0.99)$ \\
\hline $\mathrm{a}_{30}, \mathrm{~mm}$ & $0.72(0.99)$ & $0.93(0.99)$ & $0.47(0.99)$ \\
\hline $\mathrm{k}_{20}, \min$ & $1.88(0.97)$ & $2.36(0.97)$ & $1.29(0.98)$ \\
\hline IAC & $0.50(0.99)$ & $0.79(0.99)$ & $0.30(0.99)$ \\
\hline
\end{tabular}

${ }^{1} \mathrm{RCT}=$ rennet coagulation time; $\mathrm{k}_{20}=$ curd-firming time; $\mathrm{a}_{30}=$ curd firmness 30 min after addition of rennet to milk; IAC $=$ index of milk aptitude to coagulate.

from SCS class high $(\mathrm{SCS}>4.00)$ were $5.75(\mathrm{CI} 95 \%=$ 5.21 to 6.36 ) times more likely to present high SCS in subsequent test days than were observations from SCS class average.

\section{DISCUSSION}

\section{Breed Effect on Milk Yield, Composition, and MCP}

All the traits included in the present study were significantly affected by breed. Penasa et al. (2014) estimated greater milk production, lower fat, protein, and $\mathrm{CN}$ content, greater $\mathrm{RCT}$, and lower $\mathrm{a}_{30}$ for $\mathrm{HF}$ than for BS or SI. However, those authors did not include SCS as an explanatory variable in the statistical model. The lower milk production, with greater fat and protein content, and much more favorable MCP among BS than among HF cows agreed with results reported by Stocco et al. (2017).

The lower $\mathrm{Ca}, \mathrm{Mg}$, and $\mathrm{P}$ contents observed in milk of $\mathrm{HF}$ than in milk of BS or SI can be related to the lower protein and $\mathrm{CN}$ concentrations and the higher milk a

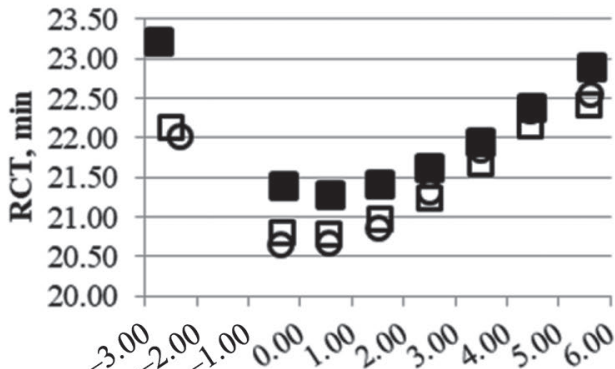

c

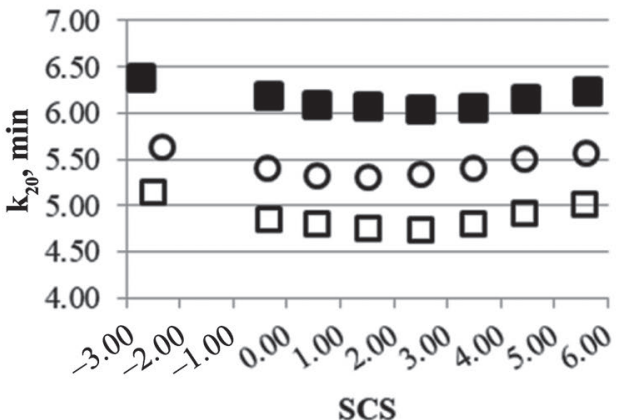

b

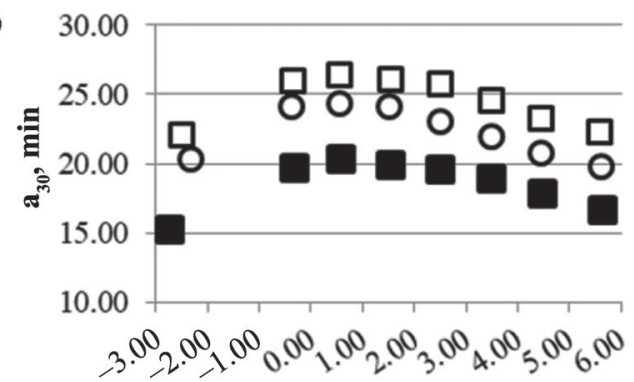

$\mathrm{d}$

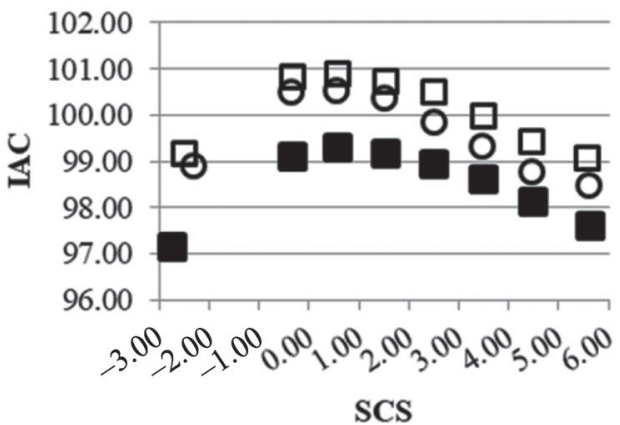

Figure 4. Least squares means of (a) rennet coagulation time (RCT), (b) curd firmness 30 min after rennet addition to milk ( $\mathrm{a}_{30}$ ), (c) curdfirming time $\left(k_{20}\right)$, and $(d)$ index of milk aptitude to coagulate (IAC) across SCS for Brown Swiss ( $\square$ ), Holstein Friesian ( $\left.\square\right)$, and Simmental ( $\bigcirc$ ) cows in multibreed herds. For each breed, represented data points are means of each variable for each SCS class. 
production of HF compared with other breeds (Toffanin et al., 2015; Visentin et al., 2018). Breed differences in milk protein profile have been reported among Swedish Red, Danish Holstein, and Danish Jersey cows (Gustavsson et al., 2014), and among HF, BS, and SI cows in single-breed herds (Franzoi et al., 2019b).

\section{High and Low SCS Similarly Impair Production Traits}

In the present study, the average milk yield loss per each SCS unit higher than 0.00 was $0.43 \mathrm{~kg} / \mathrm{d}$, in agreement with the findings of Koldeweij et al. (1999), who estimated milk yield loss of 0.39 and $0.61 \mathrm{~kg} / \mathrm{d}$ for primiparous and multiparous cows, respectively. The same authors reported protein yield loss of 0.012 and 0.016 $\mathrm{kg} / \mathrm{d}$ for primiparous and multiparous cows, respectively, similar to the average protein yield loss per SCS unit $(0.011 \mathrm{~kg} / \mathrm{d})$ of the present study. A greater fat yield loss per SCS unit $(0.025 \mathrm{~kg} / \mathrm{d})$ than the one calculated in the present study $(0.010 \mathrm{~kg} / \mathrm{d})$ has been reported by Gill et al. (1990) in dairy herds of Ontario, Canada, which could be explained by the different management practices and genetic backgrounds of the 2 populations.

Interestingly, the overall loss of milk fat and protein yields was lower at increasing SCS in HF compared with SI. The lower effect of SCS on fat yield loss for HF compared with other breeds was previously reported by MacMillan et al. (1983) for HF and Jersey cows. Distinctive traits of each breed, such as body weight, shape and size of teats, and infecting pathogens, could play a role in determining such breed-dependent differences in SCS increase (Alhussien and Dang, 2018). Considering the different patterns of neutrophil migration to the mammary gland reported for HF and Jersey cows in induced infections (Bannerman et al., 2008),

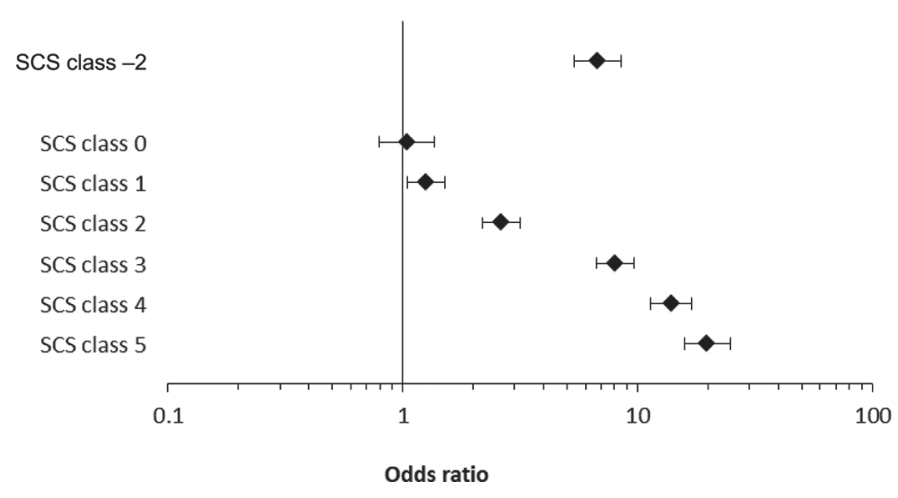

Figure 5. Odds ratios for each SCS class relative to SCS class -1 , calculated to estimate the likelihood that in at least one test day, at 30 $\pm 5,60 \pm 5$, or $90 \pm 5 \mathrm{~d}$ from the observation test day, the cow would present SCS > 4.00. Bars correspond to 95\% Wald CI. A vertical line indicates odds ratio equal to 1 , which is the case that exposure does not affect odds of outcome, compared with reference class. we hypothesized that HF might experience a greater increase of SCS for less-severe mastitis events compared with BS and SI breeds.

Based on the decrease of milk, fat, and protein yields, the present study suggested that a very low SCS (SCC $<6,250$ cells $/ \mathrm{mL}$ ) could reflect similar udder damage to that of high SCS. Very few studies have highlighted the negative effect of low SCC on dairy cow production (Tyler et al., 1989; Garcia et al., 2015). Those studies have reported lower milk loss in HF $(0.38 \mathrm{~kg} / \mathrm{d}$; Tyler et al., 1989) and Jerseys (0.92 kg/d; Garcia et al., 2015) due to low SCC than we did $(2.23 \mathrm{~kg} / \mathrm{d})$, probably because of the different cutoffs used in definitions of SCS classes and different statistical approaches.

Most studies have reported a linear correlation between SCS and milk, protein, and fat yields (Hortet and Seegers, 1998), which could be related to the exclusion of observations with SCS $<0.00$ or to the SCS class definition. Many papers have considered a unique class for observations with SCS $\leq 2.00$, which is the commonly assumed cutoff for healthy cows (Hortet and Seegers, 1998).

\section{SCS Alters Milk Detailed Composition and MCP}

The overall increase of the proportion of $\alpha-\mathrm{CN}$ and the decrease of $\beta-\mathrm{CN}$ in milk protein profiles at increasing SCS agreed with Kroeker et al. (1985) and NgKwai-Hang et al. (1987) in individual HF milk. Moreover, the trivial effect of SCS on the relative proportion of $\kappa-\mathrm{CN}, \alpha-\mathrm{LA}$, and $\beta$-LG agreed with the findings of Ng-Kwai-Hang et al. (1987). Nevertheless, the effects of other whey proteins not considered in the present study cannot be excluded. For example, Le Maréchal et al. (2011) have reported an increase of BSA and Ig in the milk of mastitic cows. Moreover, results for $\alpha$-LA should be interpreted with caution because of the low coefficient of determination $\left(\mathrm{R}^{2}=0.39\right)$ of the calibration model.

The increase observed for $\mathrm{Ca}, \mathrm{Na}, \mathrm{K}$, and $\mathrm{Mg}$, and the stability of $\mathrm{P}$ with increasing SCS reflects changes in the endothelium permeability of mastitic cows (Tallamy and Randolph, 1970) as well as a concentration effect due to reduction of milk yield. On the other hand, Summer et al. (2009) have reported lower P and K content, higher $\mathrm{Na}$ and $\mathrm{Cl}$ content, and no significant effect on $\mathrm{Ca}$ and $\mathrm{Mg}$ when comparing milk of the quarters of $10 \mathrm{HF}$ cows with SCC $<400,000$ and $>400,000$ cells $/ \mathrm{mL}$.

The overall trend in MCP variation across SCS classes is similar to the one described by Politis and Ng-Kwai-Hang (1988) for Holstein milk and by Bobbo et al. (2016) for individual BS milk. Moreover, our findings agreed with the positive correlation between SCS 
and RCT and $\mathrm{k}_{20}$, and the negative correlation between SCS and $\mathrm{a}_{30}$, reported by several authors (Jõudu et al., 2008; Le Maréchal et al., 2011). The reduction of RCT observed in the present study was similar to the 2-min reduction reported by Politis and $\mathrm{Ng}$-Kwai-Hang (1988), but these authors reported a weaker effect on $\mathrm{k}_{20}$ and $\mathrm{a}_{30}$ compared with our results. Bobbo et al. (2016) reported a quadratic polynomial relationship between SCS and RCT $\left(\mathrm{R}^{2}=0.80\right)$ and SCS and $\mathrm{a}_{30}\left(\mathrm{R}^{2}\right.$ $=0.77)$, with $\mathrm{R}^{2}$ that were lower than those obtained in the present study. To the best of our knowledge, the current study is the first to estimate the effect of very low SCS on detailed milk composition and technological traits.

\section{Best Production Performance Occurs at Specific SCS Values}

Based on the cubic model proposed in the present study, the estimated SCS values to achieve the highest milk, fat, protein, and lactose production, were mostly at SCC between 12,500 and 25,000 cells/mL (Table $3)$. Fat and protein maximum yields were found at slightly higher SCS compared with yields of milk and lactose, which agreed with the fact that intramammary infections first perturb endothelium permeability and thereafter reduce biosynthesis and secretion (Kitchen, 1981; Shuster et al., 1995; Zhao and Lacasse, 2008). Milk coagulation properties were better at higher SCS compared with milk and component yields, which can be explained by the variety of factors affecting MCP. For example, RCT could be improved at increasing SCS due to the concentration effect on milk fat, protein, and $\mathrm{CN}$ linked to milk yield reduction. Nevertheless, $\mathrm{pH}$ is known to increase with higher SCS, which can overcome the previous effect and impair RCT (Ikonen et al., 2004; Le Maréchal et al., 2011), and the proteolytic activity in mastitic cows negatively affects MCP (Le Maréchal et al., 2011).

Simmental cows revealed maximum productivity at higher SCS (milk and components yield) than the other breeds, suggesting that SI cows cope better with potential mammary infections. Holstein Friesian showed the lowest SCS for the highest production, which could indicate a lower physiological SCS value and a different relationship among mastitis, SCS, and milk quality compared with other breeds. Moreover, the evolution of milk yield and components across SCS classes showed that milk production and quality among HF started to decrease at lower SCS than among SI, even if the trend was less pronounced for the former than for the latter breed. This suggests that SCS values resulting in the most desirable productivity depend on the breed.

\section{Very Low SCS Increases Risk of Mastitis in Later Test Day Records}

The present study revealed that cows with very low SCC have higher risk of reaching high SCS in a subsequent test day compared with cows with average SCS levels. This contrasts with the findings of Whist and Østerås (2007), who reported that cows with SCC < 20,000 cells $/ \mathrm{mL}$ had the lowest risk of developing clinical mastitis. However, some species of mastitic pathogens, such as Streptococcus uberis and Escherichia coli, can weaken the host immune response (Thompson-Crispi et al., 2014). Indeed, E. coli has been associated with low SCC before emergence of clinical mastitis, indicating impaired immune efficiency in the udder (Suriyasathaporn et al., 2000). Udder quarters with SCC $<21,000$ cells $/ \mathrm{mL}$ have been linked to increased risk of clinical mastitis in HF, in particular for infections caused by coliforms (Peeler et al., 2003), and herds with a greater proportion of cows with SCC $<50,000$ cells $/ \mathrm{mL}$ had increased risk of developing clinical mastitis (Beaudeau et al., 2002). According to Rainard et al. (2018), low SCC could have a negative effect on susceptibility to infections, although they excluded that genetic selection for low SCC could have a negative influence on mastitis resistance. Still, it is not clear whether very low SCC levels are a naturally occurring clinical problem of the cow, leading to increased susceptibility to mastitis from environmental pathogens (Wellnitz et al., 2010), or whether specific pathogens are able to inhibit the migration of immune cells to the udders of infected cows (Shuster et al., 1995).

\section{CONCLUSIONS}

Results of the present study confirmed that an increase of SCC impairs milk productivity, profitability, and quality following a third-order polynomial regression, and highlighted that very low SCC $(<6,250$ cells $/$ $\mathrm{mL}$, corresponding to SCS $<-1.00)$ had similar or worse detrimental effects on milk yield and quality than high SCC (>200,000 cells/mL, corresponding to SCS $>4.00$ ). Moreover, cows with SCS $<-1.00$ in a test day were 7 times more likely to present with high SCC within the following $90 \pm 5 \mathrm{~d}$ than were cows with SCC between 6,250 and 12,500 cells/mL, corresponding to SCS between -1.00 and 0.00 . The best SCC, resulting in the highest milk yield and quality, was found between 12,500 and 25,000 cells $/ \mathrm{mL}$, corresponding to SCS from 0.00 to 1.00 , but quality of HF milk started to decrease at lower SCS compared with the other breeds, even if the effect on production at increasing SCS was less pronounced for HF. Overall, our results suggest that 
a breed-dependent optimum of SCS at test day level exists, in terms of both milk yield and quality, and that very low SCS values could be considered a risk factor for the development of mastitis and should be taken into account for herd management.

\section{ACKNOWLEDGMENTS}

The authors thank the South Tyrolean Dairy Association (Bolzano, Italy) and the Breeders Association of Bolzano Province (Bolzano, Italy) for providing data used in this study.

\section{REFERENCES}

Alhussien, M. N., and A. K. Dang. 2018. Milk somatic cells, factors influencing their release, future prospects, and practical utility in dairy animals: An overview. Vet. World 11:562-577. https://doi .org/10.14202/vetworld.2018.562-577.

Arnould, V., R. Reding, J. Bormann, N. Gengler, and H. Soyeurt. 2013. Review: Milk composition as management tool of sustainability. Biotechnol. Agron. Soc. Environ. 17:613-621.

Bannerman, D. D., H. R. Springer, M. J. Paape, A. C. W. Kauf, and J. P. Goff. 2008. Evaluation of breed-dependent differences in the innate immune responses of Holstein and Jersey cows to Staphylococcus aureus intramammary infection. J. Dairy Res. 75:291-301. https://doi.org/10.1017/S0022029908003427.

Barbano, D. M., R. R. Rasmussen, and J. M. Lynch. 1991. Influence of milk somatic cell count and milk age on cheese yield. J. Dairy Sci. 74:369-388. https://doi.org/10.3168/jds.s0022-0302(91)78179-4.

Beaudeau, F., C. Fourichon, H. Seegers, and N. Bareille. 2002. Risk of clinical mastitis in dairy herds with a high proportion of low individual milk somatic-cell counts. Prev. Vet. Med. 53:43-54. https:/ /doi.org/10.1016/s0167-5877(01)00275-6.

Berry, D. P., N. C. Friggens, M. Lucy, and J. R. Roche. 2016. Milk production and fertility in cattle. Annu. Rev. Anim. Biosci. 4:269-290. https://doi.org/10.1146/annurev-animal-021815-111406.

Bobbo, T., C. Cipolat-Gotet, G. Bittante, and A. Cecchinato. 2016. The nonlinear effect of somatic cell count on milk composition, coagulation properties, curd firmness modeling, cheese yield, and curd nutrient recovery. J. Dairy Sci. 99:5104-5119. https://doi .org/10.3168/jds.2015-10512.

Costa, A., N. Lopez-Villalobos, N. W. Sneddon, L. Shalloo, M. Franzoi, M. De Marchi, and M. Penasa. 2019. Invited review: Milk lactose - Current status and future challenges in dairy cattle. J. Dairy Sci. 102:5883-5898. https://doi.org/10.3168/jds.2018-15955.

De Marchi, M., V. Toffanin, M. Cassandro, and M. Penasa. 2014. Invited review: Mid-infrared spectroscopy as phenotyping tool for milk traits. J. Dairy Sci. 97:1171-1186. https://doi.org/10.3168/ jds.2013-6799.

Dürr, J. W., R. I. Cue, H. G. Monardes, J. Moro-Méndez, and K. M. Wade. 2008. Milk losses associated with somatic cell counts per breed, parity and stage of lactation in Canadian dairy cattle. Livest. Sci. 117:225-232. https://doi.org/10.1016/j.livsci.2007.12.004.

Feudalea, R. N., and N. A. Woody. 2002. Transfer of multivariate calibration models: A review. Chemom. Intell. Lab. Syst. 64:181-192. https://doi.org/10.1016/S0169-7439(02)00085-0.

Franzoi, M., G. Niero, M. Penasa, and M. De Marchi. 2019a. Development of infrared prediction models for diffusible and micellar minerals in bovine milk. Animals (Basel) 9:E430. https://doi.org/ 10.3390/ani9070430.

Franzoi, M., G. Niero, G. Visentin, M. Penasa, M. Cassandro, and M. De Marchi. 2019b. Variation of detailed protein composition of cow milk predicted from a large database of mid-infrared spectra. Animals (Basel) 9:E176. https://doi.org/10.3390/ani9040176.

Garcia, R. R., V. B. Maion, K. M. de Almeida, E. H. W. de Santana, M. R. Costa, R. Fagnani, and A. Ludovico. 2015. Relationship between somatic cell counts and milk production and composition in Jersey cows. Rev. Salud Anim. 37:137-142.

Gill, R., W. H. Howard, K. E. Leslie, and K. Lissemore. 1990. Economics of mastitis control. J. Dairy Sci. 73:3340-3348. https://doi.org/ 10.3168/jds.S0022-0302(90)79029-7.

Gustavsson, F., A. J. Buitenhuis, M. Johansson, H. P. Bertelsen, M. Glantz, N. A. Poulsen, H. Lindmark Månsson, H. Stålhammar, L. B. Larsen, C. Bendixen, M. Paulsson, and A. Andrén. 2014. Effects of breed and casein genetic variants on protein profile in milk from Swedish Red, Danish Holstein, and Danish Jersey cows. J. Dairy Sci. 97:3866-3877. https://doi.org/10.3168/jds.2013-7312.

Halasa, T., K. Huijps, O. Østerås, and H. Hogeveen. 2007. Economic effects of bovine mastitis and mastitis management: A review. Vet. Q. 29:18-31. https://doi.org/10.1080/01652176.2007.9695224.

Hortet, P., and H. Seegers. 1998. Calculated milk production losses associated with elevated somatic cell counts in dairy cows: Review and critical discussion. Vet. Res. 29:497-510.

IFCN Dairy Research Network. 2017. IFCN Dairy Outlook 2030 Brochure. Accessed Jan. 28, 2019. https://ifcndairy.org/wp-content/ uploads/2018/06/IFCN-Dairy-Outlook-2030-Brochure.pdf.

Ikonen, T., S. Morri, A. M. Tyriseva, O. Ruottinen, and M. Ojala. 2004. Genetic and phenotypic correlations between milk coagulation properties, milk production traits, somatic cell count, casein content, and pH of milk. J. Dairy Sci. 87:458-467. https://doi.org/ 10.3168/jds.S0022-0302(04)73185-9.

Ingvartsen, K. L., R. J. Dewhurst, and N. C. Friggens. 2003. On the relationship between lactational performance and health: Is it yield or metabolic imbalance that cause production diseases in dairy cattle? A position paper. Livest. Prod. Sci. 83:277-308. https:// doi.org/10.1016/s0301-6226(03)00110-6.

Jõudu, I., M. Henno, T. Kaart, T. Püssa, and O. Kärt. 2008. The effect of milk protein contents on the rennet coagulation properties of milk from individual dairy cows. Int. Dairy J. 18:964-967. https: //doi.org/10.1016/j.idairyj.2008.02.002.

Juhl, H. V. 2017. Method for compensating amplitude drift in a spectrometer and spectrometer performing said method. US Pat. No. 9606050.

Juozaitiene, V., A. Juozaitis, and R. Micikeviciene. 2006. Relationship between somatic cell count and milk production or morphological traits of udder in Black-and-White cows. Turk. J. Vet. Anim. Sci. 30:47-51.

Kitchen, B. J. 1981. Bovine mastitis: Milk compositional changes and related diagnostic tests. J. Dairy Res. 48:167-188. https://doi.org/ 10.1017/s0022029900021580.

Klei, L., J. Yun, A. Sapru, J. Lynch, D. Barbano, P. Sears, and D. Galton. 1998. Effects of milk somatic cell count on cottage cheese yield and quality. J. Dairy Sci. 81:1205-1213. https://doi.org/10 .3168/jds.S0022-0302(98)75680-2.

Koivula, M., E. A. Mantysaari, E. Negussie, and T. Serenius. 2005. Genetic and phenotypic relationships among milk yield and somatic cell count before and after clinical mastitis. J. Dairy Sci. 88:827-833. https://doi.org/10.3168/jds.S0022-0302(05)72747-8.

Koldeweij, E., U. Emanuelson, and L. Janson. 1999. Relation of milk production loss to milk somatic cell count. Acta Vet. Scand. 40:4756.

Kroeker, E. M., K. F. Ng-Kwai-Hang, J. F. Hayes, and J. E. Moxley. 1985. Effects of environmental factors and milk protein polymorphism on composition of casein fraction in bovine milk. J. Dairy Sci. 68:1752-1757. https://doi.org/10.3168/jds.s0022-0302(85)81023-7.

Le Maréchal, C., R. Thiéry, E. Vautor, and Y. Le Loir. 2011. Mastitis impact on technological properties of milk and quality of milk products-A review. Dairy Sci. Technol. 91:247-282. https://doi .org/10.1007/s13594-011-0009-6.

MacMillan, K. L., G. F. Duirs, and D. M. Duganzich. 1983. Association between dry cow therapy, clinical mastitis, and somatic cell count score with milk and fat production in ten New Zealand dairy herds. J. Dairy Sci. 66:259-265. https://doi.org/10.3168/jds.s0022 $-0302(83) 81785-8$

McDermott, A., G. Visentin, M. De Marchi, D. P. Berry, M. A. Fenelon, P. M. O'Connor, O. A. Kenny, and S. McParland. 2016. Prediction of individual milk proteins including free amino acids in 
bovine milk using mid-infrared spectroscopy and their correlations with milk processing characteristics. J. Dairy Sci. 99:3171-3182. https://doi.org/10.3168/jds.2015-9747.

Ng-Kwai-Hang, K. F., J. F. Hayes, J. E. Moxley, and H. Monardes. 1987. Variation in milk protein concentrations associated with genetic polymorphism and environmental factors. J. Dairy Sci. 70:563-570. https://doi.org/10.3168/jds.S0022-0302(87)80042-5.

Niero, G., M. Penasa, P. Gottardo, M. Cassandro, and M. De Marchi. 2016. Short communication: Selecting the most informative mid-infrared spectra wavenumbers to improve the accuracy of prediction models for detailed milk protein content. J. Dairy Sci. 99:1853-1858. https://doi.org/10.3168/jds.2015-10318.

Peeler, E. J., M. J. Green, J. L. Fitzpatrick, and L. E. Green. 2003. The association between quarter somatic-cell counts and clinical mastitis in three British dairy herds. Prev. Vet. Med. 59:169-180. https://doi.org/10.1016/s0167-5877(03)00076-x.

Penasa, M., M. De Marchi, S. Ton, L. Ancilotto, and M. Cassandro. 2015. Reproducibility and repeatability of milk coagulation properties predicted by mid-infrared spectroscopy. Int. Dairy J. 47:1-5. https://doi.org/10.1016/j.idairyj.2015.02.004.

Penasa, M., F. Tiezzi, A. Sturaro, M. Cassandro, and M. De Marchi. 2014. A comparison of the predicted coagulation characteristics and composition of milk from multi-breed herds of Holstein-Friesian, Brown Swiss and Simmental cows. Int. Dairy J. 35:6-10. https://doi.org/10.1016/j.idairyj.2013.10.004.

Piccinini, R., E. Binda, M. Belotti, G. Casirani, and A. Zecconi. 2005. Comparison of blood and milk non-specific immune parameters in heifers after calving in relation to udder health. Vet. Res. 36:747757. https://doi.org/10.1051/vetres:2005030.

Politis, I., and K. F. Ng-Kwai-Hang. 1988. Effects of somatic cell counts and milk composition on the coagulating properties of milk. J. Dairy Sci. 71:1740-1746. https://doi.org/10.3168/jds.s0022 -0302(88)79740-4.

Rainard, P., G. Foucras, D. Boichard, and R. Rupp. 2018. Invited review: Low milk somatic cell count and susceptibility to mastitis. J. Dairy Sci. 101:6703-6714. https://doi.org/10.3168/jds.2018-14593.

Seegers, H., C. Fourichon, and F. Beaudeau. 2003. Production effects related to mastitis and mastitis economics in dairy cattle herds. Vet. Res. 34:475-491. https://doi.org/10.1051/vetres:2003027.

Sharma, N., K. Singh, and M. S. Bhadwal. 2011. Relationship of somatic cell count and mastitis: An overview. Asian-Aust. J. Anim. Sci. 24:429-438. https://doi.org/10.5713/ajas.2011.10233.

Shuster, D. E., M. E. Kehrli, and C. R. Baumrucker. 1995. Relationship of inflammatory cytokines, growth hormone, and insulin-like growth factor-I to reduce performance during infectious disease. Proc. Soc. Exp. Biol. Med. 210:140-149.

Stocco, G., C. Cipolat-Gotet, T. Bobbo, A. Cecchinato, and G. Bittante. 2017. Breed of cow and herd productivity affect milk composition and modeling of coagulation, curd firming, and syneresis. J. Dairy Sci. 100:129-145. https://doi.org/10.3168/jds.2016-11662.

Summer, A., P. Franceschi, M. Malacarne, P. Formaggioni, F. Tosi, G. Tedeschi, and P. Mariani. 2009. Influence of somatic cell count on mineral content and salt equilibria of milk. Ital. J. Anim. Sci. 8(Suppl. 2):435-437.

Suriyasathaporn, W., Y. H. Schukken, M. Nielen, and A. Brand. 2000. Low somatic cell count: A risk factor for subsequent clinical mastitis in a dairy herd. J. Dairy Sci. 83:1248-1255. https://doi.org/10 .3168/jds.S0022-0302(00)74991-5.
Szumilas, M. 2010. Explaining odds ratios. J. Can. Acad. Child Adolesc. Psychiatry 19:227-229.

Tallamy, P. T., and H. E. Randolph. 1970. Influence of mastitis on properties of milk. V. Total and free concentrations of major minerals in skimmilk. J. Dairy Sci. 53:1386-1388. https://doi.org/10 .3168/jds.S0022-0302(70)86404-9.

Thompson-Crispi, K., H. Atalla, F. Miglior, and B. A. Mallard. 2014. Bovine mastitis: Frontiers in immunogenetics. Front. Immunol. 5:493. https://doi.org/10.3389/fimmu.2014.00493.

Toffanin, V., M. De Marchi, N. Lopez-Villalobos, and M. Cassandro. 2015. Effectiveness of mid-infrared spectroscopy for prediction of the contents of calcium and phosphorus, and titratable acidity of milk and their relationship with milk quality and coagulation properties. Int. Dairy J. 41:68-73. https://doi.org/10.1016/j .idairyj.2014.10.002.

Tyler, J. W., M. C. Thurmond, and L. Lasslo. 1989. Relationship between test-day measures of somatic cell count and milk production in California dairy cows. Can. J. Vet. Res. 53:182-187.

Tyrrell, H. F., and J. T. Reid. 1965. Prediction of the energy value of cow's milk. J. Dairy Sci. 48:1215-1223. https://doi.org/10.3168/ jds.S0022-0302(65)88430-2.

Visentin, G., A. McDermott, S. McParland, D. P. Berry, O. A. Kenny, A. Brodkorb, M. A. Fenelon, and M. D. Marchi. 2015. Prediction of bovine milk technological traits from mid-infrared spectroscopy analysis in dairy cows. J. Dairy Sci. 98:6620-6629. https://doi.org/ 10.3168/jds.2015-9323

Visentin, G., M. Penasa, P. Gottardo, M. Cassandro, and M. De Marchi. 2016. Predictive ability of mid-infrared spectroscopy for major mineral composition and coagulation traits of bovine milk by using the uninformative variable selection algorithm. J. Dairy Sci. 99:8137-8145. https://doi.org/10.3168/jds.2016-11053.

Visentin, G., M. Penasa, G. Niero, M. Cassandro, and M. De Marchi. 2018. Phenotypic characterisation of major mineral composition predicted by mid-infrared spectroscopy in cow milk. Ital. J. Anim. Sci. 17:549-556. https://doi.org/10.1080/1828051x.2017.1398055.

Wellnitz, O., A. Baumert, M. Saudenowa, and R. M. Bruckmaier. 2010. Immune response of bovine milk somatic cells to endotoxin in healthy quarters with normal and very low cell counts. J. Dairy Res. 77:452-459. https://doi.org/10.1017/S0022029910000348.

Whist, A. C., and O. Østerås. 2007. Associations between somatic cell counts at calving or prior to drying-off and clinical mastitis in the remaining or subsequent lactation. J. Dairy Res. 74:66-73. https:/ /doi.org/10.1017/S0022029906002172.

Wiggans, G. R., and G. E. Shook. 1987. A lactation measure of somatic cell count. J. Dairy Sci. 70(Suppl. 13):2666-2672. https:// doi.org/10.3168/jds.S0022-0302(87)80337-5.

Zhao, X., and P. Lacasse. 2008. Mammary tissue damage during bovine mastitis: Causes and control. J. Anim. Sci. 86:57-65. https:// doi.org/10.2527/jas.2007-0302.

\section{ORCIDS}

M. Franzoi ๑ https://orcid.org/0000-0001-8701-5632

C. L. Manuelian 잔 https://orcid.org/0000-0002-0090-0362

M. Penasa @ https://orcid.org/0000-0001-9984-8738

M. De Marchi ๑ https://orcid.org/0000-0001-7814-2525 